\title{
Photoperiod Responses of Some Japanese Chrysanthemums
}

\author{
F. A. LANGTON \\ Glasshouse Crops Research Institute, Littlehampton, Sussex (U.K.)
}

\begin{abstract}
Summary
In a study of photoperiod response, twenty-two Japanese cultivars were compared with five cultivars normally grown in English all-year-round (AYR) schedules. Cultivars which naturally flower in Japan in September or earlier (early-flowering) reacted as quantitative short-day plants. Both flower bud initiation and development occurred more rapidly in short days (SD) as compared with long days (LD). Only the cultivar, Mezame, approached day-neutrality. Autumn and winter-flowering (lateflowering) cultivars responded as quantitative short-day plants, as did the English AYR cultivars. The early-flowering cultivars differed from the late-flowering types in that lateral flower buds and often the terminal flower buds developed to anthesis in LD.

The number of leaves produced in LD before terminal bud initiation by the earlyflowering Japanese cultivars increased as natural flowering season became later. It seems likely, therefore, that long-day leaf number plays a part in determining natural flowering season in these cultivars. Similarly bud development time in SD may play a part in determining natural flowering season in the late-flowering cultivars.
\end{abstract}

At least two of the Japanese cultivars possessed characteristics which might usefully be incorporated into English AYR cultivars.

\section{Introduction}

Studies on the chrysanthemum (C. morifolium Ramat.) at the Glasshouse Crops Research Institute (GCRI), Littlehampton, U. K., have until recently been concerned only with cultivars grown by all-year-round (AYR) producers of cut flowers and flowering pot plants. These chrysanthemums all have similar flowering responses; they flower naturally in the short days (SD) of the English autumn, and in long days (LD) show delayed flower bud initiation, arrested bud development and, eventually, flower bud abortion. This photoperiodic control of flowering is the basis for AYR growing. LD are created in the glasshouse in spring, autumn and winter by night-break lighting, and SD are provided in summer by the use of black-outs. The temperature is kept at a level considered to be best both for rapid flower bud initiation and development. Temperature manipulation is not feasible since plantings are made weekly with the result that plants at all stages of development occur

Received for publication September 20, 1977 together within the same glasshouse.

AYR production in Europe and N. America depends mainly on environmental manipulation and is very different from that practised in Japan where the emphasis is on the growing of cultivars which differ in flowering response so that they naturally flower at different times of the year (5). It might be useful to combine these approaches by introducing characters from Japanese cultivars in to English AYR cultivars to give novel types suitable for glasshouse growing at particular times of the year. With this in mind, the photoperiodic responses of twenty-two Japanese cultivars spanning the range of commercially grown types were compared with five cultivars grown by English AYR producers.

\section{Materials and methods}

The cultivars used are listed in Table 1. Cuttings of the Japanese cultivars, which were originally kindly supplied by Dr. J. Kawata of the Vegetable and Ornamental Crops Research Station, Tsu-City, were taken from stock plants maintained in LD at GCRI. 
The stock plants had been vernalised at $5^{\circ} \mathrm{C}$ for four weeks prior to cuttings being taken. Cuttings of the English AYR cultivars were purchased from commercial propagators who had also maintained their stock plants in LD. All cuttings were rooted in LD given by a four-hour light interruption (minimum $60 \mathrm{~lx}$ ) in the middle of each dark period.

The rooted cuttings were planted in John Innes No. 2 compost in $12.5 \mathrm{~cm}$ pots and established in $\mathrm{LD}$ in a glasshouse at $12^{\circ} \mathrm{C}$. They were fed as required using a mineral nutrient solution. After five to ten days they were transferred to $16.8^{\circ} \mathrm{C}$ average night minimum, a temperature conducive to flower bud initiation and development (1) and one which is usual in English AYR growing. Transfers were made in early March, 1975.

The terminal portion of the main stem of each plant was removed ('pinched') immediately above the eighth leaf at the time of transfer to the higher temperature. Only the lateral shoot from the axil of the seventh leaf was allowed to develop, and this became the main stem. This procedure has been recommended by Cockshull (4) in order to minimise variation between replicate plants; the onset of shoot growth is synchronised and shoots spend their whole period of growth in the conditions of an applied treatment.

After transfer, half the plants of each cultivar were given $\mathrm{SD}$ while the other half continued to receive LD. SD were given by extending each daily dark period to fourteen hours using black-outs and LD were given, as earlier, by night-break lighting. The plants were not disbudded and were grown as 'sprays'. The trial comprised sixteen plants per cultivar in a two block, split-plot design with cultivars assigned to sub-plots. This allowed the comparison of cultivars within daylength treatments and daylength effects within cultivars. $\log _{e}$ transformations were necessary in all analyses of variance.

The number of leaves and bracts below the terminal flower bud on each main stem (seventh lateral) was counted and used as a measure of the effect of iphotoperiod treatment on flower bud initiation. Similar counts were also made on each uppermost lateral shoot which grew out from the main stem after initiation of the terminal bud. The effect of photoperiod on flower bud development was measured by calculating the time taken for terminal buds to reach anthesis after first becoming visible. The dates on which the bud-visible stage and anthesis were reached were determined by twice weekly examinations. Anthesis was taken as Stage 8 on the scale of Cockshull and Hughes (2).

\section{Results and discussion}

Okada (8) classified the chrysanthemum cultivars which are grown in Japan on the basis of their responses to temperature and photoperiod. He distinguished Summer, August and September flowering cultivars from $\mathrm{Au}$ tumn and Winter types on the basis that bud initiation in the former groups is not affected by photoperiod i.e. they are day-neutral. The latter groups respond more rapidly in SD. Okada further reported that the Summer and August chrysanthemums are day-neutral for flower bud development unlike the remainder which require SD to produce open blooms.

Summer, August and September cultivars

The twelve cultivars listed in Table 1 from Fuji to Mizuho were taken to represent these three groups of chrysanthemums and are hereafter referred to as early-flowering cultivars. All produced fewer leaves and bracts below the terminal flower bud in SD compared with LD (Table 1). The differences were significant $(P<0.05)$ in all except Mezame, Shimano-kagayaki and Asama-no-yuki. Whilst these latter three cultivars behaved as dayneutrals with respect to flower bud initiation, the other nine cultivars reacted as quantitative short-day plants. As was expected, the English AYR cultivars also reacted as quantitative short-day plants by producing far fewer leaves in $\mathrm{SD}$ than in $\mathrm{LD}$ before initiating terminal buds.

The early-flowering cultivars produced more leaves on their uppermost lateral shoots in LD than in SD (Table 1). The differences were less marked than those shown by the English AYR cultivars but they are, nevertheless, symptomatic of a short-day hastening of lateral bud initiation in the Japanese cultivars.

Terminal flower buds on all of the early- 
Table 1. Leaf and bract numbers in short days (SD) and long days (LD).

\begin{tabular}{|c|c|c|c|c|c|}
\hline Cultivar & $\begin{array}{l}\text { Flowering period in } \\
\text { AYR growing* }\end{array}$ & $\begin{array}{l}\text { Main } \\
\text { SD }\end{array}$ & $\begin{array}{l}\text { stem } \\
\text { LD }\end{array}$ & $\begin{array}{l}\text { Uppermost } \\
\text { SD }\end{array}$ & $\begin{array}{l}\text { lateral } \\
\text { LD }\end{array}$ \\
\hline Fuji & June & 14.4 & 20.3 & 2.8 & 3.9 \\
\hline Kinriki & June/July & 12.0 & 23.5 & 2.0 & 11.5 \\
\hline Ensyunada & June & 14.6 & 34.4 & 2.4 & 5.0 \\
\hline Mezame & July & 28.7 & 30.0 & 0.0 & 0.0 \\
\hline Shima-no-kagayaki & July & 36.9 & 42.0 & 0.0 & 2.9 \\
\hline Myoko-no-hoshi & August & 45.8 & 55.4 & 0.0 & 9.5 \\
\hline Shiho & August & 21.8 & 43.5 & 0.0 & 5.6 \\
\hline Hareginu & August & 35.8 & 50.0 & 1.5 & 7.1 \\
\hline Asama-no-yuki & August & 44.6 & 50.0 & 0.0 & 4. 1 \\
\hline Tosho & September & 35.3 & 54.9 & 0.4 & 19.4 \\
\hline Seiun & September & 32.3 & 59.4 & 0.0 & 14.1 \\
\hline Mizuho & September & 33.9 & 56.4 & 0.8 & 11.9 \\
\hline Seiko-no-hana & October & 18.5 & 51.9 & 2.6 & 44.6 \\
\hline Chiyozakura & November & 22.8 & 76.3 & 0.1 & - \\
\hline Kurenai & November & 24.4 & 36.5 & 2.6 & 16.1 \\
\hline Okina-no-tomo & November & 23.7 & 49.8 & 0.0 & 33.0 \\
\hline Shirotsubaki & late November & 27.5 & 42.8 & 4.4 & 32.9 \\
\hline Azuma-no-hikari & late November & 19. 8 & 19. 8 & 4.1 & 13.6 \\
\hline Tenryu-no-asa & December & 28.1 & 42.7 & 2.9 & 33.0 \\
\hline Kankoyuki & December & 19.4 & 30.5 & 3.0 & 32.4 \\
\hline Kanfubuki & December & 35.7 & 70.0 & 7.1 & - \\
\hline Kankobai & December & 21.9 & 30.1 & 0.0 & 33.8 \\
\hline Pollyanne & January to December & 9.5 & 32.9 & 1.0 & 23.6 \\
\hline Snowdon & January to December & 16.2 & 53.8 & 0.6 & 33.9 \\
\hline Polaris & April to October ${ }^{\dagger}$ & 11.3 & 43.0 & 1.4 & 23.4 \\
\hline Light Melody & December to April ${ }^{\dagger}$ & 12.3 & 36.3 & 0.0 & 30.7 \\
\hline Delmarvel & October to April ${ }^{\dagger}$ & 13.5 & 41.6 & 3.4 & 29.4 \\
\hline
\end{tabular}

* Information concerning Japanese cultivars kindly provided by Dr. J. Kawata.

- These cultivars can be flowered without difficulty from January to December but are cropped by choice only in the periods which are shown.

flowering cultivars reached anthesis in SD but eight of the twelve cultivars showed bud abortion in LD (Table 2). Only Fuji, Ensyunada, Mezame and Shima-no-kagayaki reliably produced flowering terminals when grown as "sprays" in LD. However, with the exception of Mezame, these cultivars took significantly $(\mathrm{P}<0.05)$ longer to reach anthesis in LD compered with SD (Table 2). Cultivars such as Kinriki which showed complete terminal bud abortion in LD produced open flowers on the lateral shoots. The English AYR cultivars, in contrast, produced neither terminal or lateral blooms in LD.

Whilst the early-flowering Japanese cultivars differed in some important resepects from the English AYR cultivars they still reacted as quantitative short-day plants for both flower bud initiation and development. All except three initiated terminal flower buds more rapidly in SD. Even the exceptions, Mezame, Shima-no-kagayaki and Asama-no-yuki initi- ated significantly $(\mathrm{P}<0.05)$ fewer leaves in $\mathrm{SD}$ than in LD in a subsequent trial (7). Only Mezame behaved as a day-neutral cultivar for flower bud development. These conclusions that early-flowering cultivars are quantitative short-day plants are in contrast to those of Okada (8).

The photoperiodic reactions of the earlyflowering Japanese cultivars were very similar to those reported for eighteen summer-flowering English cultivars (7). It is interesting that in both groups of cultivars the number of leaves produced before the terminal flower bud in LD, a genetically determined character (4), tends to be larger as natural flowering season becomes later. Table 1 shows that leaf numbers in LD range from 20.3 for the earliest cultivar, Fuji, to 59.4 for Seiun, a September-flowering cultivar. Long-day leaf number might therefore, in part, explain natural flowering season differences between earlyflowering cultivars. Leaf initiation rate and 
Tabl 2. Flower bud development in short days (SD) and long days (LD).

\begin{tabular}{|c|c|c|c|c|c|}
\hline Cultivar & $\begin{array}{l}\% \text { terminal buds } \\
\text { reaching anthesis } \\
\text { in LD }\end{array}$ & $\begin{array}{l}\text { Time to } \\
\text { anthesis } \\
\text { SD }\end{array}$ & $\begin{array}{l}\text { reach } \\
\text { (days) } \\
\text { LD }\end{array}$ & $\begin{array}{l}\text { Time from } \\
\text { to anthesis } \\
\mathrm{SD}\end{array}$ & $\begin{array}{l}\text { bud visible } \\
\text { (days) } \\
\text { LD }\end{array}$ \\
\hline Fuji & 100 & 56.4 & 80.8 & 28.4 & 50.7 \\
\hline Kinriki & 0 & 53.5 & - & 25.5 & - \\
\hline Ensyunada & 100 & 55.8 & 100.8 & 27.8 & 56.4 \\
\hline Mezame & 100 & 71.6 & 82.2 & 32.1 & 37.1 \\
\hline Shima-no-kagayaki & 100 & 77.2 & 97.8 & 31.5 & 41.2 \\
\hline Myoko-no-hoshi & 0 & 85.5 & - & 29.5 & - \\
\hline Shiho & 80 & 74.8 & 134.7 & 37.3 & 58.5 \\
\hline Hareg inu & 13 & 84.4 & - & 38.4 & - \\
\hline Asama-no-yuki & 88 & 87.2 & 118.1 & 23.9 & 50.6 \\
\hline Tosho & 0 & 85.2 & - & 33.8 & - \\
\hline Seiun & 0 & 71.8 & - & 30.1 & - \\
\hline Mizuho & 13 & 85.0 & - & 36.1 & - \\
\hline Seiko-no-hana & 100 & 64.0 & 132.1 & 35.8 & 67.6 \\
\hline Chiyozakura & 0 & 68.2 & - & 34.9 & - \\
\hline Kurenai & 0 & 78.6 & - & 41.8 & - \\
\hline Okina-no-tomo & 0 & 72.7 & - & 37.1 & - \\
\hline Shirotsubaki & 0 & 102.6 & - & 61.8 & - \\
\hline Azuma-no-hikari & 0 & 99.2 & - & 59.0 & - \\
\hline Tenryu-no-asa & 0 & 90.4 & - & 52.7 & - \\
\hline Kankoyuki & 0 & 98.4 & - & 67.9 & - \\
\hline Kanfubuki & 0 & - & - & - & - \\
\hline Kankobai & 0 & 77.9 & - & 44.9 & - \\
\hline Pollyanne & 0 & 55.6 & - & 31.6 & - \\
\hline Snowdon & 0 & 61.2 & - & 36.4 & - \\
\hline Polaris & 0 & 52.9 & - & 28.9 & - \\
\hline Light Melody & 0 & 52.0 & - & 28.0 & - \\
\hline Delmarvel & 0 & 66.8 & - & 38.3 & - \\
\hline
\end{tabular}

the time taken from flower bud initiation to anthesis in LD are two further factors which can be expected to influence natural flowering season. The role of temperature (8) was not tested in the present work.

Langton and Cockshull (6) have suggested characteristics that might be possessed by the ideal cultivar for summer growing in English AYR schedules. Ensyunada, a June-flowering cultivar appeared to approach this ideal in at least three important respects.

Firstly, it produced a fairly large number of leaves in LD, 34.4 (Table 1), which compared well with Pollyanne, 32.9 a cultivar which is currently grown in summer in England. Even this number is rather low however; it is important that English AYR cultivars have the capacity to initiate high leaf numbers in LD before budding so that the incidence of premature budding is low (3).

Secondly, it rapidly initiated flower buds in SD. Experience suggests that at the time of stopping, when SD began, the axillary buds giving rise to the main stems had about six to eight leaf primordia. It is clear from Table 1 that some cultivars such as Myoko-nohoshi continued to initiate leaves long after SD had begun. Ensyunada, however, responded to SD as rapidly as the English AYR cultivar, Snowdon; Ensyunada had flowering stems bearing 14. 6 leaves whilst Snowdon had stems with 16.2 leaves.

Thirdly, and most importantly, Ensyunada reliably produced open blooms in LD. This suggests that the cultivar could be flowered in summer with only a brief period of SD, perhaps of two weeks, to initiate flower buds. Current AYR cultivars used in England require SD for at least six weeks to achieve rapid and even flowering. Such long periods of blacking-out are costly to the grower because of the labour input, and the resulting high temperatures can be injurious to the plants. Disease incidence can also be increased due to condensation under the black-outs. The trial which is reported here gave no indication of the effect on total cropping time of returning Ensyunada to natural LD after 
only two weeks of SD. Whilst continuous LD delayed anthesis, cropping time in SD (55. 8 days) compared favourably with the average for the three English AYR cultivars which are grown in the summer (56. 6 days).

Autumn and Winter cultivars

The cultivars listed in Table 1 from Seikono-hana to Kankobai were taken as representative of these late-flowering chrysanthemums. All except Azuma-no-hikari showed delayed terminal flower bud initiation in $\mathrm{LD}$ $(\mathrm{P}<0.05)$, and all showed delayed lateral flower bud initiation (Table 1). All developed their terminal buds to anthesis in SD but only Seiko-no-hana, an October-flowering cultivar, bloomed in LD. This cultivar took significantly $(\mathrm{P}<0.05)$ longer to reach anthesis from the bud-visible stage in LD compared with SD (Table 2). With the possible exception of Azuma-no-hikari, therefore, all of the cultivars reacted as short-day plants for both bud initiation and development and well fitted the classification of Okada (8) in this respect.

Several of the late-flowering Japanese cultivars showed extremely slow flower bud development in SD. Table 2 shows that Kankoyuki, for example, took 67.9 days to reach anthesis from the bud visible stage. This contrasts with the average of 31.7 days for the early-flowering cultivars, and with 32.6 days for the English AYR cultivars. The four cultivars which flower in October and November averaged 37.4 days whilst the five which flower in late November or December averaged 57.3 days. It seems probable, therefore, that this characteristic plays a part in determining natural flowering season.

None of the Japanese late-flowering cultivars appeared to be immediately suitable for growing in English AYR schedules. Most showed both delayed flower bud initiation and slow bud development in SD. On the other hand, certain of the cultivars possessed characteristics which might usefully be incorporated into new cultivars for English AYR growing. Chiyozakura, for example, showed a much greater capacity than the English AYR cultivars to produce large numbers of leaves in LD before initiating a flower bud. This character would help reduce stock maintenance problems and, since it has an extremely high broad sense heritability, there should be response to selection (6).

The contrasts in AYR chrysanthemum production methods in the U.K. and Japan emphasize how divergent paths can be taken when both genotype and environment substantially affect phenotypic response. It is abundantly clear that East and West have much to offer each other in the future improvement of chrysanthemum production techniques.

\section{Literature Cited}

1. Cathey, H.M. 1954. Chrysanthemum temperature study B. Thermal modifications of photoperiods previous to and after flower bud initiation. Proc. Amer. Soc. Hort. Sci. $64: 492-498$.

2. Cockshull, K.E. and Hughes, A.P. 1972. Flower formation in Chrysanthemum morifolium : the influence of light level. J. Hort. Sci. 47 : 113-127.

3. 1975. Premature budding in yearround chrysanthemums. Rep. Glasshouse Crops Res. Inst. 1974 : 128-136.

4. 1976. Flower and leaf initiation by Chrysanthemum morifolium Ramat. in long days. J. Hort. Sci. $51: 441-450$.

5. KAWATA, J. 1969. Year-round production of chrysanthemums in Japan. Jap. Agric. Res. Q. $4: 23-27$.

6. LAngton, F.A., and K.E. Cockshull. 1976. An ideotype of chrysanthemum (C. morifolium Ramat.) Acta Hort. $63: 165-175$.

7. LANGTON, F. A. 1977. The responses of early-flowering chrysanthemums to daylength. Scientia Hort. (In press).

8. OKADA, M. 1957. Classification of chrysanthemum varieties in view of their environmental responses to flowering. J. hort. Ass. Japan. $26: 59-72$. 
日本産切花ギクの日長反応

F.A. ラントン

(イギリス温室作物研究所)

摘要

イギリスで普及している周年生産切花用 5 品種を対照 ている.

に用いて, 日本産切花用 22 品種の日長反応を調査した. 夏ギクおよび $8 \cdot 9$ 月咲き品種では, 自然開花期の遅 これらのらち, 日本における自然開花期が 9 月以前の夏 ギクおよび $8 \cdot 9$ 月咲き品種は，量的短日植物（quantitative short-day plant) の反応を示した. すなわち, い品種ほど, 長日下で花房形成までに形成される葉数が 增加した. したがって, 長日下で形成される葉数は, 夏 ギク和よび $8 \cdot 9$ 月咲き品種の自然開花期を決定する一 花芽の分化とその発達は, 長日下ょり短日下で促進され た。 しかし，“めざめ”は中性に近い反応を示した．秋 ギク打よび寒ギクも，イギリスの周年生産用品種と同様 に, 量的短日植物の反応を示した. しかし, 夏ギクおよ び $8 \cdot 9$ 月咲き品種は, 長日下で側らいあるいは主らい が開花に至るといら点で, 秋ギク・寒ギク品種と相違し 要因となっているものと思われる。また，短日下におけ る花芽発達の遅速は, 秋ギク・寒ギクの開花期を決定す る一要因であるとみられる.

供試した日本産品種のらち, 少くとも 2 品種の特性は, イギリスの周年生産用品種の改良に有用であると考えら れた。 